\title{
Sweet Potato: A Miracle Crop for Soil and Water Conservation Under Rainfed Maize in India's North-Western Himalaya: An Opinion
}

ISSN: 2637-7659

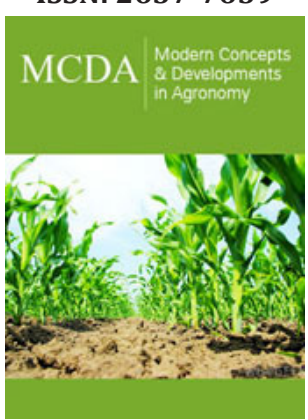

*Corresponding author: Devideen Yadav, Scientist, ICAR-Indian Institute of Soil and Water Conservation, Dehradun, 248195, India

Submission: 漈July 19, 2021

Published: 些July 22, 2021

Volume 9 - Issue 1

How to cite this article: Devideen Yadav M Madhu. Sweet Potato: A Miracle Crop for Soil and Water Conservation Under Rainfed Maize in India's North-Western Himalaya: An Opinion. Mod Concep Dev Agrono. 9(1). MCDA. 000705. 2021. DOI: 10.31031/MCDA.2021.09.000705

Copyright@ Devideen Yadav. This article is distributed under the terms of the Creative Commons Attribution 4.0 International License, which permits unrestricted use and redistribution provided that the original author and source are credited.

\author{
Devideen Yadav* and M Madhu \\ ICAR- Indian Institute of Soil and Water Conservation, Dehradun, India
}

\section{Opinion}

The soil resource of India's North-Western-Himalayan Region (NWHR) is fruitful, and numerous crops are cultivated there. Rainfed maize is the most prevalent crop in NWHR, covering 0.33 million hectares. Several production egresses currently limit maize's full productivity potential by diminishing the region's natural resource sustainability, namely land and water. Soil erosion is one of the most important issues among them, resulting in significant soil and water loss. If farmers continue to use traditional corn-growing practices, soil loss due to erosion in NWHR on a slope of $4 \%$ can reach up to $30.0 \mathrm{t}$ ha-1 at times [1]. Due to erosion, traditional rainfed corn farming loses a substantial amount of soil nutrients, including $25-30 \mathrm{~kg}$ of nitrogen, $1.0-1.5 \mathrm{~kg}$ of phosphorus, $20-20 \mathrm{~kg}$ of potassium, and $300-$ $350 \mathrm{~kg}$ of carbon per hectare. Corn has morphological characteristics that expose a larger area of the soil, rendering it sensitive to erosion. Most soils are subject to erosion since the sole maize crop only covers 20-30 percent of the soil surface up to 30 days after sowing (Figure 1).

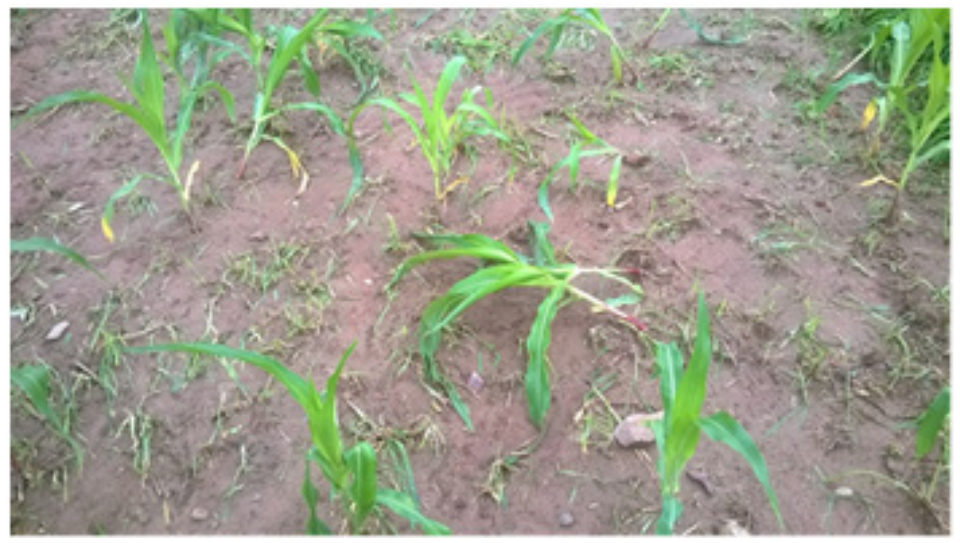

Figure 1: Soil erosion is exacerbated by the lack of cover under maize crops.

\section{Soil erosion control under maize is achieved by cultivating sweet potato}

Sweet potato can be cultivated with maize to decrease the problem of soil erosion. In comparison to solitary maize, which only covers $30 \%$ soil at this stage, sweet potato cultivated as an intercrop in maize gives up to $60 \%$ soil coverage at 30 days following sowing. Raindrop velocity is reduced by the dense foliage of sweet potatoes, which traps them on their leaves. 
As a result, the soil will be protected from high-intensity rain, which can cause serious soil erosion. According to the research, growing sweet potato with maize reduces soil loss to 1.5-2.0 tons per hectare at a $2 \%$ soil slope. Sweet potato roots can penetrate up to one meter into the soil, increasing water absorption while reducing runoff. Aside from the highest quality tubers, this crop produces roughly 7.5-8.0 tons of dry biomass per hectare. The carbon composition of its biomass is $40.0 \%, 1.5-2.0 \%$ nitrogen, $0.15 \%$ phosphorus, and $1.05 \%$ potassium. A hectare of biomass can recycle roughly $3467 \mathrm{~kg}$ of carbon, 135 kilograms of nitrogen, $10 \mathrm{~kg}$ of phosphorus, and $80 \mathrm{~kg}$ of potassium. Sweet potato biomass degrades quickly in the soil and transforms to compost due to its low carbon to nitrogen ratio. There will be a significant increase in carbon and soil nutrient content by adding sweet potato residues to the soil (Figure 2).

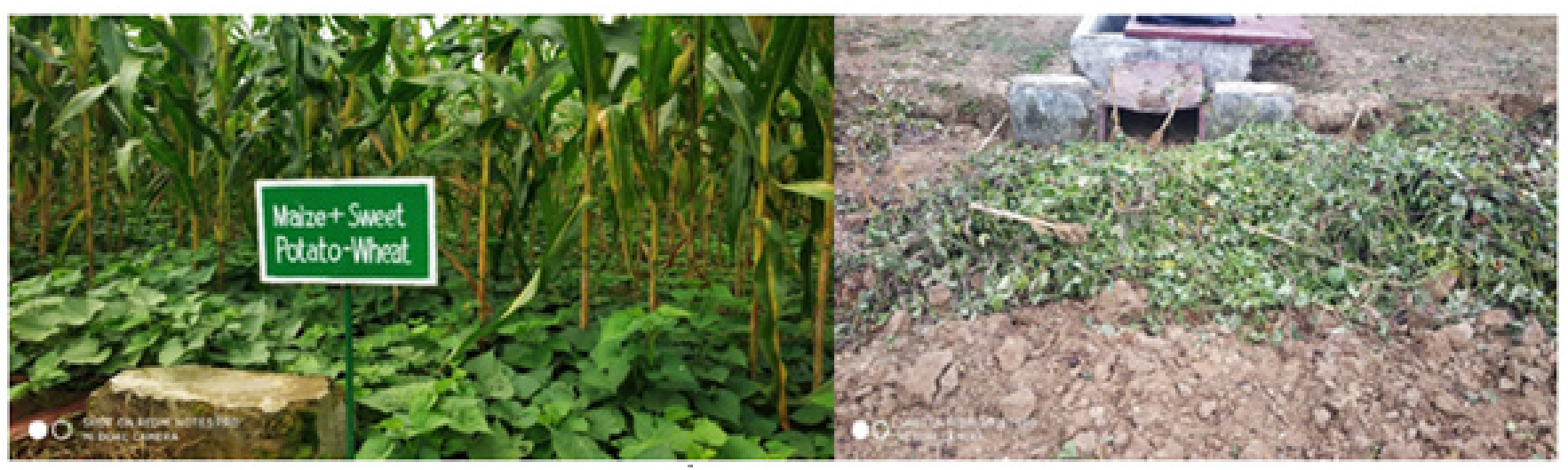

Figure 2: Sweet potato as a maize intercrop and the massive biomass it produces.

\section{Conclusion}

Soil erosion is a key issue with NWHR rainfed maize. Farmers can reduce soil erosion by cultivating sweet potato with maize at a low cost and without compromising maize productivity. Farmers in the region can quickly adopt the techniques, and as a result, they are becoming more interested in cultivating it. As a result, cultivating sweet potato with maize is a promising step toward sustainable maize production and excellent soil and water resource management in the NWHR region of India.

\section{References}

1. Sharma NK, Singh RJ, Mandal D, Kumar A,Alam NM, etal. (2017) Increasing farmer's income and reducing soil erosion using intercropping in rainfed maize-wheat rotation of Himalaya, India. Agriculture, Ecosystems \& Environment 247: 43-53. 